\title{
Textual And Contextual Meaning Of Rapal Mantra Suwuk: The Religious Aspect In The Perspective Of Ritual Language
}

\author{
Harsono $^{1}$ \\ \{sonsjava@gmail.com\} \\ ${ }^{1}$ Veteran Bangun Nusantara University of Sukoharjo
}

\begin{abstract}
Suwuk is an activity of reciting traditional Javanese spell (mantra) for ancient healing and repelling disaster. One of the behavior of the ancient Javanese people is still found in rural areas. In suwuk there is a spell that is recited by a shaman. The spell in Javanese is called japa or prayer. Suwuk spell is believed by some Javanese people who believe that its existence has power, as a medium to ask God to adapt to Javanese culture in their language. Suwuk mantra is an intangible cultural asset that needs special treatment to document it. That is why an in-depth study of the shaman's spell rapal is needed. In an effort to provide explanations about the meaning and interpretation of meaning in the rapal spell. The analysis is done by using the method of contextual method and understanding method. The data source in this study was the suwuk shaman in Jatipuro village karanganyar district and the data in the form of transcription of the suwuk shaman spell obtained through unstructured interviews with the shaman. The results of this study conclude that suwuk spell has a construction of textual and contextual meaning which functions for introspection, purification, supplication, and hope. Self-introspection in an effort to re-experience, and give thanks for God's blessings and gifts. Purification in an effort to purify oneself through prayers in an effort to escape from the disturbing negative interference. A supplication, in an effort to restore the identity of the person who get suwuk for escape from the bad influences by Sawan. Hope, in an effort to expect God's blessing so that in the future life's journey will always be blessed, given safety, health and the glory of life.
\end{abstract}

Keywords: spell, suwuk, nyuwuk, religiosity, ritual language

\section{Introduction}

Regional culture is a manifestation of the results of local genius community to provide a representation of the civilization reality who inhabit it. The civilization in culture originating from the noble and sacred values system by community institutions in a place passed down from generation to generation. The ideal form of culture is tradition which functions as a manner. The cultural value system is the most abstract level of tradition. A cultural value system consists of conceptions that live in the minds of most citizens, about things that they must consider very valuable in life. Therefore, a cultural value system usually functions as the highest guideline for human behavior. Indonesia has become one of the countries with diverse 
cultural products. In social life, cultural value systems are associated with attitudes that influence human behavior. Regional cultural values are patricularistic, meaning that they are generally accepted in the culture of certain ethnic groups [1].

This diversity makes national culture invaluable. One of them is Javanese culture. It is interesting to examine the cultural behavior of Javanese people living in rural areas. According to Geertz's historical representation, before the advent of Hinduism, the Javanese were animists. In about AD 400, Hinduism, and then Buddhism, began to gain a stronghold [2]. One of them is the custom of the village community or Javanese society in the past, namely to do medicinal treatment with suwuk. Suwuk is an activity for alternative medicinal treatments of traditional Javanese society. The intermediary of this medicinal treatment is a shaman, by reciting a spell to the patient. In suwuk, there is a spell that is recited by a shaman. Shamans whom we in the "civilized world have called "medicine men" and "witch doctors". These shamanic methods are strikingly similar the world over [3]. The shaman's spell uses Javanese language and known as a mantra.

Mantra is believed by some Javanese society who believe that its existence has power, as a manifestation of media requests for God, and useful for various specific purposes of the shipper. When a person reads a mantra, it is believed that the person is in communication with the Almighty. Mantra is very difficult for ordinary people to understand. This matter caused by the sound of the mantra is difficult to understand or interpret [4]. In interactional terms, this may be heard as an adequate response provided the shaman is not positioned as having expertise in magic [5]. The existence of a shaman 'Dukun' in Javanese society has a sacred value and position within society [6].

Given the widespread scepticism among psychologists about the existence of paranormal phenomena, this asymmetry is hardly surprising, but as research in the sociology of scientific knowledge has shown, there is much to be learned from a symmetrical approach to matters of controversy such as the paranormal [5]. If seen from the aspect of the language, spell sare sounds or a collection of word lexicons that have the power of meaning and suggestibility for those who read or who hear them. Every region in Indonesia generally has a spell as the verbal cultural heritage of its society. Usually spell in the regions use their respective regional languages, so spellin Javanese society that use Javanese language. From the point of view of the language, mantra suwuk use language that is sometimes difficult to understand. Even sometimes, a shaman of suwuk himself does not understand the true meaning of the word from the spell that is read. In this case, spell casters suwuk only understand when, how, and for what purpose the spell was pronounced. Rapal Suwuk has meaning and purpose in each lexicon he said. This study tries to analyze the textual rapal suwuk spell to find out the meaning and interpretation of textual meanings pronounced by a shaman of suwuk. Rapal suwuk spell has a high value of meaning and interpretation in each of its words. This is the meaning that builds the effectiveness of the rapal when used for those who believe it. In fact, the method of healing suwuk through a shaman is still carried out in the country side.

The importance of discourse as an arena in which beliefs about the paranormal are expressed has received little attention [5]. However, not many people can have the ability to be nyuwuk. This research is considered necessary, because suwuk is an intangible form of cultural assets that requires special treatment to document it and the informant is a shaman from Bonage village, Jatipuro district Karanganyar regency of the last generation, so it is very necessary to document his spells as material for language study in the future to be came as a form of conservation of cultural heritage. 


\section{Research Methods}

This research uses descriptive qualitative method. Descriptive methods namely the presentation of data based on the phenomenon and the fact that it empirically found in the collection of data. Experience phenomenon is thus structured around expectations and breaks with those expectations in ways directly relevant to what we want to derive from research [7]. After the data analysis done, then the results will be presented in an informal, namely the entire results of the findings of the study are in the form of symbolic, action, with the words of the usual which is technical. In other words, the data display methods by informal methods [8]. By the data display method informally is expected to facilitate an understanding towards each outcome research. However, it is clear that the interactional context in which the data to be discussed arose was not one of everyday discourse [5].

The data source in this research is the result of interviews with informants that supports of the research. The informant is shaman of suwuk in Bonage village, Jatipuro District of Karanganyar, Central Java. The informant is a shaman who is believed by the society to be an effective shaman of suwuk and he is the last generation of the Javanese suwuk shaman. The data in this study were recorded data of oral speech of mantra suwuk that had been transcribed into written form.

The data collection technique is done by recording technique. Audio-visual recording techniques are used to preserve the data of events, both the speech and the shape of objects and the actions observed. The steps to the recording technique are done by taking video images of suwuk implementation. Through this recording media the researchers can be helped to obtain important data that if not recorded in the field notes. Furthermore, the researchers can analyze the rapal mantra of spell even though the event has passed. The data records that have been collected are then transcribed into written language. Then from the results were done coding. The results of this coding will be used as data and then an analysis of the data will be applied.

\section{Results And Discussion}

In fact suwuk medicinal treatment is still carried out by some Javanese who believe in it. This traditional type of traditional medicine is still preserved by some traditional Javanese society. Shaman of Suwuk is known for their power in addressing the prayers for streamlining the affairs of human beings with their goals. they believe that anything could hap- pen based on the will of Allah Ta'ala [6].

Based on the suggestion or high trust, make these traditional medical habits difficult to be abandoned by the society. In general, the spell by a shaman of suwuk is in fact capable of build high suggestions for what he has rhymed with as well as society's behavior towards suwuk treatment. Change towards a speech pattern which does not coincide with that of the inter- locutor also involves cases of more persistent change towards the features and values of a community with which our Hearer/Speaker wishes to identify on a permanent basis[9]. Some of them are believed by the society, suwuk is effective in treating diseases of spirits, fussy babies or children who always cry and get fever because of sawan. The concept of Sawan must be cured or eliminated by doing suwuk. Sawan is a disease that usually attacks baby and children due to metaphysical disorders.

The phenomena of sawan become a personal threat to the affected baby, therefore there is a need for a healer and remover for the sawan by suwuk. Javanese people know 
that sawan comes from the children who are invited to the place where people die, or the babies are invited to the wedding venue. This seems strange indeed, but that is how the Javanese

know sawan.

The concept of sawan comes from ancient mythology javanese society laden with philosophical elements, as part of tradition[10].

According to studies in etnomedicine a disease suffered by society in general can be caused by two factors. First, diseases caused by agents (figures) such as gods, supernatural beings, human beings, and so on. This view is called personalistic medical systems in the study of etnomedicine. The disease can also be caused due to disruption of the body's balance because the elements remain in the body such as heat to cold and so on. This study is called natural or non-natural studies in the term etnomedicine are naturalistic medical systems. The reality of the two principles overlaps, but it is very useful to discuss the concepts in etnomedicine studies[11]. Suwuk is believed to be able to repel the sawan through a spell rapal mantra pronounced by a shaman. As a type of literature, mantras become unique and interesting because of the existence of an expressive poem in them[12].

A textual and contextual approach is needed to find out the contents of the Suwuk spell text so that it can build a strong suggestibility for healing. Rapal spell is a prayer of hope that is said in an effort to build self-confidence and confidence, so that from the rapal spell works to be able to give the expected luck. In the textual suwuk spell has a deep meaning value as a form of hope to God and is a form of respect for all of His creation. Even though the words that have been drawn from the rapids of the suwuk spell use the culture of the beliefs and reliance of doer as a form of Javanese cultural inheritance. For some Javanese people who still believe in the suwuk spell and like are a form of belief in the religiosity subculture that is used by the wearer as a representation of Javanese religious religiosity in terms of medicine. The mantra is strongly influenced by the religious magical atmosphere of the wearer's community. The most influential are Hinduism, Buddhism, Islam and beliefs. In subsequent developments, the four influences are mutilated and mutilated spells are assimilative[13]. The following is mantra Suwuk:

Bismilahirohmannirohim, lahamdulilahhirobilngalamin

Singgah-singgah kala singgah,durgamala sumingkira

Banyu putih, banyuabang, banyukuning, tansah konjuk martopura sakkendhaga, guagarbane (mother's name) sangang sasi sepuluh wengi, lahir (patient's name) raga kusumo karo midodari sekethi bambaran sari mbukakkori ne sijabang bayi (patient's name) (while blowing $3 \times$ the crown of the child)

Kiblat papat lima pancer, kakang kawak adi ari-ari, Kakang kawah saanut dalane mungkir, dalan sumingkir, ewangana nolak sarap sawane si jabang bayi (patient's name), tangkepane dandanganne (nama anak) senthek kluwer bajang sarane, sarat bangke bisa mele, sarat wedhang bias ilang, sarat gembok bisa iglog, luntur sarap sawane gogrogana (patient's name) panggonane, omah sangar, kali angker, padhaspel Lara lan sarap sawan kang manggon sajroning sungsum lambarane balung, anak kulit ana otak, sajroning grana, ana sedayala rasa jroning badan (patient's name), panggonane omah sangar, kali angker padas pel, aja nyambangi badane (blow the fontanel) Nek abang pas kuning dadiya abang, rembesing banyu dadiya adhem, Singgah singgah kala singgah, durgakala sumingkira, Tuma tata jampine adas kulawaras sinerana shalawat landzikir tegese dzikir marang srikanjeng nabi allohummawalajiburni, alaihi jabang bayi si (patient's name) aja nangis aja aja guguh (sianak digeser untuk menghadap barat) 
Mencorong maglong-maglong badan awake jabang bayine (patient's name) padhang mburi, ,padhang ngarep, padhang sekabehe, donga lan wilujeng dhumateng (patient's name) waluyo jati temah mulya.

The meaning of the spell above can be built from textual. The meaning of the textual construction is closely related to the contents of a text as a whole. In the text, although the same word appears, but different types of texts can result in different meanings constructed. At the time this spell is recited by the shaman of suwuk it is not gradual as above, but in full is recited. If we examine the spell unconsciously it is divided into four stages of the construction of textual and contextual meanings which function for: self - introspection, self- purification, supplication, and hope.

\section{Self-intropection}

The construction of the textual and contextual meaning at the stage of self-introspection, the meaning of text emphasizes more on the telling of the birth cycle of the child who wants to be suwuk. The spell starts with the prayer of Bismilahirohmannirohim, In the name of Allah, the Most Merciful and The Most Gracious, Alhamdulillahirobbilalamin , all our praise to Allah SWT, who has provided health and tranquility in this life. In the opening sentence this spell is a form of gratitude. Furthermore, the telling of how the union of the sperm (semen) fluid tangible white, red, and yellow are united in fertilization maternal womb by mother for nine months and ten days, then the baby was born (which in suwuk). If the baby was born male (raga kusuma) or female (midodari sekethi bambaran sari) to especially the patience (child's name). Based on the construction of the textual meaning it can also be built on the contextual meaning that in the first phase or stage the rapal suwuk chant is pronounced. From the text, the spell caster seems to open a time machine to be able to recount the story of the child's journey (who get suwuk) starting from when he was still in his mother's womb. This seems to provide understanding to the child's parents, that it is appropriate to thank and gratitudeto God for the gift given by the son. When it is related to the context, the spell caster wants to invite the parents of the child to rely on all that only God Almighty as an effort to escape from the suffering of child affected by sawan. The birth of the child is due to the grace and greatness of God Almighty, so it is also believed that by His permission and greatness $\mathrm{He}$ is also requested to be released from all the pain and suffering of the child. In the spell, one of the Javanese suluk is also inserted, which is the Singgah-singgah kala singgah durgakala sumingkira. This sentence is an extract of the whole form of suluk which is believed by the Javanese people to have great magical power for those who believe it.

The suluk stopover text in the suwuk spell above is only taken up to the second stanza. Nevertheless at least it has been able to provide an understanding that the stanzais expected to be able to provide magical power and has represented for the whole essence of the suluk which is as a repellent for all forms of creatures and forms of reinforcements that will interfere with all expected to disappear. On rare occasion, one of her "clients" might show up unannounced. It was to be expected in her line of work and she didn't necessarily mind, unless they were possessed [14].

\section{Purification}

In this section, the textual and contextual meaning is a form of self-purification. Koentjaraningrat explains the concept of the five categorization. Referring to the first stanza keblat papat lima pancer can in find categorization based Koentjaraningrat as important categorization in the classification of symbolic on the culture of Java, namely the 
categorization of five's[15]. This are manifested in the symbol keblat papat which means four directions, and is a regular proceed with kalima pancer means point toward the fifth as center.

The Javanese society also recognizes the system that is based on the categorization of the five, which is more important, namely the category in the fourth direction of the eyes of the wind and the fifth in the middle. This concept is believed and understood the community of Java to connect a system of classification of symbolic based on five categories with a view of the perception of the stability and harmony of life[15].The correlation of meaning regarding the four directions and one that becomes the center that basically the center (pancer) is what plays an important role in maintaining balance in the four directions. In the recitation of the mantra Suwuk, the appearance of this sentence is in an attempt to synergize the four elements of the cardinal direction which is likely to bring a bad influence on a person. The center (pancer) is expected to be a guardian of these bad influences. Further contextual analysis found that the use of the term keblat has links with Islamic doctrine. In Islam the mention of directions with the term keblat in carrying out the prayer. Keblat enabled the absorption of Arabic languageis the Qiblat. The correlation is certainly can be reinforced that the teachings of the Islamic religion does have a lot of influence the lives of the culture of Java through the process of history in long time.

After the sentence 'keblat papat lima pancer' the mantra followed by hope for everything that has a detrimental effect disappeared and returned to their respective homelands. It can be observed in the sentence "luntur sarap sawane gogrog ana panggone omah sangar kali angker padhas pel' which means that all bad influences coming from the four corners of the compass can fade and all return to their respective places. If it comes from a haunted house, comes from a haunted river or comes from rocks, all should be able to return to its origin. It is this concept of returning to its origin that also emphasizes that respect for the cosmos and the microcosm is shown that even though everything related to the evil does not ask to be removed, it is more desirable to return to its origin or place. This emphasizes the concept of respecting the balance of the order of life, that there are good and some bad, good hopes place occupies its place and the bad return to the place of origin to be able to live in the best order according to their respective places and not interfere with each other. Thus there is the concept of Javanese life wisdom in the wisdom of life towards nature and its surroundings.

\section{Supplication}

At this stage the essence of the textual meaning of the spell is the emphasis of any wish desired by the spellcaster of suwuk. In the first and second stanzas the request for convulsions attached to the marrow, to the brain, skin, nose and to the whole body is expected to be completely gone. Contextually, the construction of meaning can be built that in the body is supported by the marrow and brain which is a vital role in the human body.

Important parts in the human body are specifically mentioned, starting from the innermost (marrow) to the outermost (skin). Both of these can be interpreted, that the specific request is profoundly expected by the spellcaster to be given a healing symbolized by the marrow (the deepest) as well as a whole bodily request represented by the skin (which coats the entire entire body). The in-depth and comprehensive application is expected for convulsions originating from 'haunted houses, haunted riverbanks and rock solids' not to interfere and return to their respective origins by being blown on the crown of the baby as a sign of hope in depth and comprehensive is able to be represented by the exhalation of air exhaled by the shipper to ward off all the bad influences in the child's body. Furthermore, in the textual it also mentions 'nek abang pas dadi kuning dadi ya abang', 'when red turns yellow becomes red'. The red and yellow colors in this spell. If judging from the standpoint of the philosophy of 
meaning, in the Javanese society also respect to the beauty of the colors. This is evidenced by the frequent occurrence of Javanese traditional ceremonies that use color in symbolization for requests and expectations, for example, It manifested in jenang (soft and sticky textured food from processed crops in the form of flour) which is colorful (jenang abang,kuning putih).

The philosophical meaning of jenang abang is a representation of human origins made from blood plasma so that in important ceremonies the Javanese society is sometimes found jenang abang, which is a representation of gratitude to God for the existence and life of humans on this earth. The yellow color in jenang kuning represents the lust of greedy, the lust that exists in human beings that is needed self-control to balance it. The context of the suwukspell above which refers to nek abang pas dadi kuning dadiya abang' when red turns yellow becomes red', gives the understanding that, if the red color that has the basic foundation of gratitude has changed to yellow which is the caution in life, please return to red. In this case, the spell invites to return to the true path to always be grateful to God. So in the end, rembesing banyu dadiya adhem' the drops of water makes it cold' which gives the meaning that it is hoped that the red color which becomes yellow is able to turn red again accompanied by the water droplets to make it holy again and always grateful for God's gift, so that the peace of life is represented by adhem or cold words we can enjoy. The feeling of 'adhem' which represents a sense of peace and serenity should always be performed in prayer and remembrance of God.

In the continuation of the spell, it is mentioned that 'tuma tata jampine adas kulawaras sinerana shalawat lan dzikir tegese dzikir marang sri kanjeng nabi allohumma walajiburni // alaihi jabang bayi si (nama anak) /laja nangis aja aja guguh // (sianak digeser untuk menghadap barat), so that it is arranged then the cure is adas kulawaras which means to get healthy as a whole should be accompanied by blessings and remembrance to God. With the shifting of the child's body which is pointed to face west, more emphasis on the request for us to always face the direction of Qiblat (west) the direction in which Muslims pray in prayer facing the Qiblat. In this case the request is closed with the hope that we will always be grateful in blessings and dhikr and worship to always remember the God Almighty, the source of all healing.

\section{Hope}

There is textual contextual phase is expected in the form of hope for an out of spellcasters to the patient. Hope for the opening of aura and charisma to return to normal. This last spell is the core of the spellcaster expectation to the patient. Contextually, the patient (baby) is a phase of the beginning of the cycle of human life, where in this phase required illumination 'pepadhang'. Shine in the soul, qolbu, and heart to avoid the bad influences that will disrupt his life journey later. The sentences mencorong maglong-maglong 'shining light' to hope the essentials, to constantly work benefit for o rang else around it. It is hoped that the aura of the patient will shed light on others. So that contextually the sentence mencorong maglongmaglong 'shining light' has a complex interpretation. Apart from being aside for him self, he is also expected to be able to have a positive influence on the people who will be around to accompany the baby's life journey. Padhang mburi 'light in the behind' is expected by anyone or anything that accompanies, supporting from behind is able to light also in the course of his life. In this case the parents are always behind the child, so this hope for the child's parents also always gets happiness in life. Padhang ngarep 'the light in front of ' expected anyone or anything that is in front of the child, as a guide for determine towards good or good things and become pepadhang 'illumination' child in achieving the future. The rapal of the spell is closed with padhang sekabehe, donga lan wilujeng dhumateng (the name of the patient ) waluya jati 
temah mulya, 'light everything with prayers of salvation to all, healthy and well-being and full of glory', which has meaning for the light of all the patients' lives with the accompaniment of a prayer of salvation, may the patient always be in the grace of God, given health and full of glory in life.

Back to the essence of human life to always be grateful and pray to get the blessing of God Almighty, in order to be given ease, smoothness, safety, health, glory and happiness in life [17]. Rapal mantra suwuk is also a prayer which contains the constellation of life to be always mindful and alert. Eling 'remembers' to always remember God, for the gifts given and the waspada 'caution' that gives understanding to always be careful in living life. Suwuk spell becomes part of the form of human communication to the Essence of God who has everything. The form of communication is represented in a string of sentences of hope in a manner composed by the spellcaster of suwuk.

\section{Conclusions}

In fact, treatment with a shaman is still found in traditional Javanese society today. Traditional Javanese society is still profess and believes in magical, mystical and invisible things. So that the existence of the practice of suwuk with a shaman as intermediaries is still believed by some people who believe it to be a solution to the adverse effects of metaphysics (sawan) on babies, although on the other hand they have also adopted and recognized the patterns of modernity.

At least the mantra suwuk occupies its role in traditional societies as fragments of what remains in the patterns of life and times that have developed and are still attached to and influence the patterns of social and cultural life of people who believe in it.

Mantra suwuk treatment on metaphysical disorder patients (babies) through the intermediary of a shaman, in textual and contextual have meaning construction: introspection, purification, supplication, and hope.

Self-introspection is an effort to re-live, and give pleasure to the blessings and gifts of God Almighty. Purification is an attempt to purify the patient (baby) by prayers in an attempt to escape the disturbances sawan metaphysical disturbed. Supplication is an attempt to restore the identity of the baby and escape the bad influences brought by sawan. Hope is an attempt to God Almighty bless expect that in the future the life of the baby is always blessed, given the safety, health and the glory of life. Suwuk spell occupies role as a religious ritual. This can be interpreted from the textual and contextual structure of the language which is a concept of a gift from the Almighty, so that its nature is related to supernatural power. Suwuk is a ritual in which there is a mixture of several religious doctrine and beliefs, in this case the teachings of Islam, Hindu, Buddhism and Pre-Hindu beliefs. This mixture is called syncretism. This syncretic system is commonly called the Agami Jawi system. Javanese Hindu Buddhism mantra are not always mystical, but there are elements of aesthetics and lessons of life[16]. So it can be concluded Suwuk ritual growth and develops in the Agami Jawi belief system which it contains concepts of human entities as the jagad cilik(microcosm), hoping for accord, balance, harmony and stability in the jagad gedhe (macrocosm) by presenting requests in ritual language. 


\section{References}

[1] Soehardi, "Nilai-Nilai Tradisi Lisan Dalam Budaya Jawa," Humaniora, vol. 14, no. 3. pp. 1-13, 2012, doi: 10.22146/jh.v14i3.763.

[2] A. G. Muhaimin, The Islamic Traditions of Cirebon: Ibadat and Adat Among Javanese Muslims : Ibadat and Adat Among Javanese Muslims, no. July. Australia: ANU E Press The Australian National University, 2006.

[3] M. Harner, "The Way Of The Shaman.” A Bantam Book, Publisher by Harper \& Row, Inc, New York, 1982

[4] Z. Deby Tri Ramadhani, Bakhtaruddin Nst, "Mantra Pambarasiah Diri Dalam Masyarakat Kelurahan Korong Gadang kecamatan Kuranji Kota Padang,” Progr. Stud. Sastra Indones. FBS Univ. Negeri Padang, 2013.

[5] P. Lamont, C. Coelho, and a. Mckinlay, "Explaining the unexplained: warranting disbelief in the paranormal," Discourse Stud., vol. 11, no. 5, pp. 543-559, 2009, doi: $10.1177 / 1461445609340978$.

[6] R. T. Arini, M. Y. Alimi, and G. Gunawan, "The Role of Dukun Suwuk and Dukun Prewangan in Curing Diseases in Kediri Community," Komunitas Int. J. Indones. Soc. Cult., vol. 8, no. 2, pp. 328-338, 2016, doi: 10.15294/komunitas.v8i2.4461.

[7] M. Pickering, "Research methods for cultural studies," Res. Methods Cult. Stud., 2008.

[8] Sudaryanto, Metode dan Aneka Teknik Analisis Bahasa: Pengantar Penelitian Wahana Kebudayaan secara Linguistis. Duta Wacana University Press, 1993.

[9] W. B. Hollmann, Cognitive sociolinguistics. Berlin,New York: Walter de Gruyter GmbH \& Co. KG, D-10785, 2017.

[10] Ferry Hidayat, "Pengantar Menuju Filsafat Indonesia." 2005.

[11] G. M. dan A. Foster, Medical Anthropology. New York: John Wiley \& Sons., 1978.

[12] Edi Suwatno, "Bentuk Dan Isi Mantra," Humaniora, vol. 16, no. 3, pp. 321-331, 2004, doi: 10.22146/jh.v16i3.1312.

[13] A. Aswinarko, "Kajian Deskriptif Wacana Mantra," Deiksis, vol. 5, no. 2, pp. 119-129, 2013.

[14] M. T. GREEN, "Shaman Healer Heretic," J. Chem. Inf. Model., vol. 53, no. 9, pp. 1689-1699, 2019, doi: 10.1017/CBO9781107415324.004.

[15] Koentjaraningrat, Kebudayaan Jawa. Balai Pustaka, 1994.

[16] D. Sekarbatu, "Struktur, Makna, Dan Fungsi Mantra Hindu-Jawa," J. Ilm. Kebud. Sint., vol. 7, no. 2, pp. 154-163, 2013.

[17] K. Saddhono, N. E. Wardani, and C. Ulya. "Sociopragmatic approach on discourse structure of friday prayer's sermon in java and madura island." J. of Lang and Lit, vol. 6 no. 1 pp 26-29, 2015 . 